\title{
Editorial
}

Shena Ashley and Dennis R. Young*

\section{Editors' Note to Special Symposium Issue on Nonprofit Competition}

DOI 10.1515/npf-2014-0024

This special issue of Nonprofit Policy Forum is a direct outgrowth of the Nonprofit Competition and Policy Research conference held in Washington DC in October, 2013, jointly sponsored by the Maxwell School of Citizenship and Public Affairs of Syracuse University and the Nonprofit Studies Program of the Andrew Young School of Policy Studies of Georgia State University. Following regular journal procedure, papers presented at that conference were peer-reviewed and revised prior to acceptance and publication in this issue. The historical roots of this effort trace back several years, when faculty and doctoral students in the Andrew Young School gathered to discuss their mutual interests in the subject of nonprofit sector competition. Some of us were motivated by the observation that nonprofit resource providers and business leaders often berated the sector for its growth, proliferation, and duplication of services. We wondered why such "competition" was seen as virtuous in the business sector but not for nonprofits, especially as new forms of for-profit social enterprise were being simultaneously encouraged and nurtured. Others of us were struck by the paucity of research and scholarly attention to the subject of nonprofit sector competition, and we felt that a contribution could be made by examining the subject in an objective and rigorous way. Still others were interested in the public policy implications of nonprofit competition, and the extent to which existing laws and policies governing business competition could or should apply to nonprofits.

We all recognized that this is an expansive and multifaceted subject that elicits mixed reactions. To pursue their mission, nonprofits compete for a wide

\footnotetext{
*Corresponding author: Dennis R. Young, Andrew Young School, Georgia State University, Atlanta, GA, USA, E-mail: dennisryoung@gsu.edu
}

Shena Ashley, Maxwell School, Syracuse University, Syracuse, NY, USA,

E-mail: shashley@maxwell.syr.edu 
array of inputs, including: revenue, customers, clients and audience members, labor, land and physical capital, and a host of advantages from media attention to prestige to political power. The significant growth in the sector - with over 2.3 million nonprofits operating in the U.S. - is one major source of the increasing competitiveness. Other sources include the expansion of commercial activity among nonprofit organizations, the increasing entrepreneurial impulse being propelled by social entrepreneurism, the entrance of for-profit firms into the nonprofit space, and shrinking revenue sources. Taken together, these forces have created an environment where nonprofit managers, to varying degrees, contend with a dizzying variety of forms of competition in markets populated exclusively by nonprofits and in mixed market settings.

Some view this increased competition as a positive development, citing the prospect that, like the for-profit sector, heightened competition can improve performance, increase efficiency, and reduce costs. Others are wary of these claims and raise fears that competition promotes misreporting of administrative costs on financial reports, directs energy away from the core mission work, causes service organizations to cherry-pick clients, and stifles creativity by raising entry costs.

We can leave aside for now the question of whether more or less competition is good for the nonprofit sector. It is a complex question, and there are important perspectives on both sides. Before we can even engage in such a normative discussion, we need to understand something of the dynamics.

The papers presented in this issue do not claim to be comprehensive or definitive. Our hope is to open up the subject for greater scrutiny and research, and objective assessment and policy development. At the same time we believe that the papers published here make real contributions to the advancement of knowledge about nonprofit competition and public policy.

We launch this issue with two papers that are intended to establish empirically some of the facts on the ground. The first paper by Jeremy Thornton and Teresa Harrison asks whether the density of nonprofit organizations has been increasing in the United States - a question that reflects the popular concern about having "too many nonprofits". Examining density allows the authors to take a more nuanced look at this issue by taking account of population growth and other factors to put the absolute growth in numbers of nonprofits into proper perspective. Thornton and Harrison find that nonprofit markets are not actually becoming more crowded, contrary to the popular view. This is an important finding - indeed there are now fewer nonprofits per market than in prior decades and it takes a larger population of citizens to support entry of a nonprofit into the marketplace than it has in the past.

The second paper, by Amanda Wilsker, Bruce Seaman, and Dennis Young, takes a different approach - applying and extending methods to measure the 
concentration of nonprofit industries using criteria traditionally applied for anti-trust purposes in the business sector. The results here indicate that few nonprofit markets can be described as highly competitive and that a large fraction would be considered monopolistic by business policy standards. Both the Thornton/Harrison and the Wilsker/Seaman/Young papers emphasize the fact that the available concepts and measures of density and concentration do not directly reflect actual levels of competition. Factors other than how dense nonprofits are in a given market, or how much activity is concentrated in a few organizations within an industry and locality, also influence the vigor of competition. But even with these imperfect measures, the results offered here suggest that it is reasonable to be skeptical about claims that competition among nonprofits is excessive or necessarily inefficient.

The third paper by Elizabeth Searing examines the history of applying antitrust policy and regulations to the nonprofit sector. Perhaps surprisingly, case law in this field stretches back half a century. Noting that anti-trust cases typically focus on pricing and service availability issues, Searing provides a new typology of nonprofit-related markets so that the appropriateness of applying conventional anti-trust policy tools in various contexts can be better judged. The fourth paper by Shena Ashley extends the analysis of nonprofit competition as it relates to government policy. Ashley finds that such government policies go far beyond anti-trust per se, into issues of funding and regulation as well. She presents a complex picture of the effects of government policy on nonprofit competition at two levels - impacts on the conditions in markets where nonprofits participate and impacts on individual organizations that compete in these markets. Given Ashley's review, it is clear that no analysis of nonprofit competition can ignore the complex framework of government policies within which such competition takes place. The fifth paper by Heather MacIndoe focuses on one slice of the governmental/nonprofit interface - that of public policy advocacy activity. MacIndoe finds that both competition among nonprofits and specialization by nonprofits (into narrow fields of service rather than broad general programming) positively influence the level or intensity of policy advocacy in which nonprofits are inclined to engage. This is an encouraging finding for those concerned that only the more powerful and concentrated nonprofit institutions can ultimately influence public policy.

In the sixth paper, Lewis Faulk takes on the almost Herculean task of making sense of nonprofit competition through existing theory on the role and behavior of nonprofits in a market economy and democratic society. Faulk combines strands of demand and supply-side nonprofit theory with theory of issue salience in the public sector, to offer new insights about the market contexts in which we can expect to find competition between nonprofits and for-profits as well as among nonprofits themselves. 
In our final paper, Kate Cooney takes an investor perspective, carefully examining the methodological issues associated with measuring social returns on investment (SROI) as a performance metric for nonprofits operating in different kinds of markets. This analysis should prove valuable for nonprofit resource providers of various stripes, including governmental funders, as well as for nonprofit managers and leaders of nonprofit and other social enterprises.

Finally, in our Feature section we offer two book reviews. The first is a review by Andrea Bassi of David Billis's recent book Hybrid Organizations and the Third Sector. As Billis's book makes clear, the issue of nonprofit sector competition is only becoming more important and more complex over time, as new forms of social purpose organizations compete for service markets, resources, and favorable treatment in public policy. One of those forms is public/private partnership. The second review by Stuart Mendel examines a new e-book focused on that subject, entitled Third Sector, Partnerships and Social Outcome: The Cases of Italy and Ireland, edited by Lucia Boccacin.

We hope you enjoy reading the issue and that it will encourage further research on the critical issues surrounding nonprofit competition. 